\section{More on Silver Spring monkeys}

SIR-G. Christopher Anderson's article, "Fight over Maryland monkeys" (Nature 343,297 ; 1990) fails to provide appropriate information, context and background for the events and people involved.

Anderson describes the 17 monkeys in the "Silver Spring monkeys case" as having been "rescued" by police from inhumane conditions. This is colourful writing, but it is incorrect. Dr Taub was never convicted to keeping monkeys in inhumane conditions. He was explicitly acquitted of 118 of 119 original charges. The final charge, that of failing to provide necessary veterinary care to one (of 17) monkeys, was based on the contention that the animal had osteomyelitis that was the result of improper care. Galvin, the prosecuting attorney cited in Anderson's article, alluded to osteomyelitis several times in his closing remarks, despite his being aware that a pathology report clearly stated that the animal did not have osteomyelitis. After the appeal at which the one remaining charge against Taub was overturned, Galvin left the Maryland State's Attorney's office and became president of the Washington DC chapter of Lawyers for Animal Rights.

Thus, after five years in the courts, all the original 119 counts were dismissed. Animal rights groups invariably describe this as having been based on a technicality and Anderson presents this evaluation uncritically. The facts are otherwise. The decision of the court states that the Maryland Animal Cruelty Statute did not apply to federally funded laboratories because their practices (and specifically those of Taub) were already fully regulated and supervised; this included, but was not limited to, "periodic announced and unannounced inspections pursuant to the animal welfare act". Moreover, Taub has been further exonerated by four separate investigations.

What then happened in Taub's laboratory? Nine years ago, Alex Pacheco, an animal rights extremist, infiltrated Taub's laboratory as a "volunteer worker". During this time, Pacheco took photographs which several witnesses testified did not resemble conditions they had ever witnessed in Taub's laboratory. Pacheco's photograph of a monkey that he had helped to place in a primate-restraining chair has been used extensively for propaganda by People for the Ethical Treatment of Animals (PETA). PETA routinely acts as a publicist for the Animal Liberation Front, which is listed as a terrorist organization by the Federal Bureau of Investigation and Scotland Yard. PETA promptly receives copies of photographs, videotapes and documents stolen from laboratories during illegal break-ins by the ALF and other groups. Pacheco is co- founder and director of PETA.

In the ensuing years, disputes over the custody and legal status of the monkeys have been exploited for publicity by PETA. The monkeys are at present housed at the Delta Regional Primate Center at Tulane University. Wher the monkeys were evaluated by panels of independent, distinguished veterinarians, killing was recommended for some of the monkeys whose health had deteriorated. PETA vigorously protested against this decision and secured a restraining order to prevent their being killed. The order was overturned in court and one of the monkeys was killed in January 1990. Three were killed in early July. Following a specially designed plan, investigators made electrophysiological measurements of neural activity in the brain while the monkeys were under anaesthesia just before being killed. Spinal cord and brain tissue were taken at autopsy. There is significant potential here for development of new treatments for victims of stroke and spinal cord injury. Nobel Laureate David Hubel, immediate past-president of the Society for Neuroscience, and many other distinguished neuroscientists have attested to the great value of the unique information gained from investigations of the brains of monkeys with limbs that had been deafferentated for many years.

After the death of the first monkey, animal rights activists vowed to return to the courts to prevent the killing of any of the survivors, and the Physicians' Committee for Responsible Medicine (PCRM) filed a complaint with the Department of Health and Human Services. Dr Neal Barnard, quoted by Anderson, is a Washington, DC, psychiatrist who opposes the use of animals in research. He is a medical adviser to PETA and heads PCRM. At its June 1990 meeting, the American Medical Association publicly criticized PCRM for misrepresenting the critical role animals play in research. The AMA reaffirmed the overwhelming support of physicians for the need for continuation of research.

The activists' preference for prolonging the lives of animals in failing health will ensure live material for several more years of publicity but can be of little comfort to the monkeys. The "saga of the Silver Spring monkeys" has been widely used to attack all biomedical research using animals. PETA and PCRM are not unbiased sources of information. Your readers deserve a more critical review of the issue.

Department of Microbiology \& S. B. GALSWORTHY Immunology,

University of Western Ontario,

Health Sciences Centre,

London, Canada N6A 5C1

\section{Europe's future}

SIR-When European governments "conduct themselves in a seemly fashion" (Nature 348, 267; 1990), not only do they promote the ideals of Western civilization, but they also foster a much needed spirit of decency and hope in countries which, to this day, suffer the indignation and suppression of kaiserian or stalinistic acts.

The interdependence of European peoples expressing common ideals and actions will become a social phenomenon. If we fault their chief actors for lack of imagination in Paris, we must be inspired by the persistence, faith and joy of Prague and the peoples of Eastern Europe as a whole.

The three Baltic countries of Estonia, Latvia and Lithuania were more than "nominally independent states" a few years ago, they were full members of the League of Nations until the Second World War left them occupied, much as Kuwait is today. It is noteworthy that in Paris, both the Soviet parliament of Estonia and the National Congress of Estonia (elected by citizens of the Republic of Estonia) had sent delegations, but these were rejected by their seemingly "civilized" partners.

I, too, look forward to the convening of the real Congress of Paris.

ILLIMAR ALTOSAAR

Faculty of Medicine, University of Ottawa,

40 Marie Curie Street,

Ottawa, Ontario, K1G 1X2, Canada

\section{Hunger strike}

SIR-In connection with the letter "Hunger strike" from V. Gurzadyan (Nature $347,610 ; 1990)$ on the hunger protest of Professor Victor Ambartsumian against violations of the human rights of Armenian inhabitants in the mountainous Karabagh region of Azerbaijan, the Committee of Astronomy of the Polish Academy of Sciences, representing the astronomical community of Poland, declares its full solidarity with the oppressed Armenians and expresses its deepest concern about the health of Professor Ambartsumian, one of the most distinguished scientists of this century and former president of the International Astronomical Union and of the International Council of Scientific Unions.

The Committee of Astronomy appeals to the astronomical institutions of the Soviet Union and to all international scientific organizations to take all possible steps in support of the protest of Professor Ambartsumian.

ROBERT GLEBOCKI (Chairman)

Committee of Astronomy,

Polish Academy of Sciences,

Warsaw, Poland 